
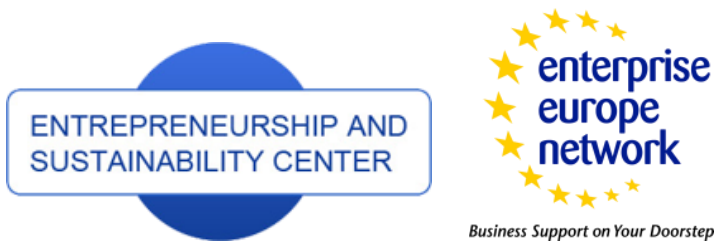

Business Support on Your Doorstep
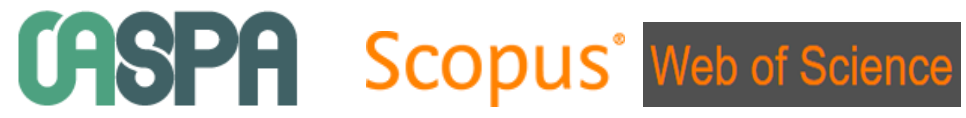

Publisher

http://jssidoi.org/esc/home

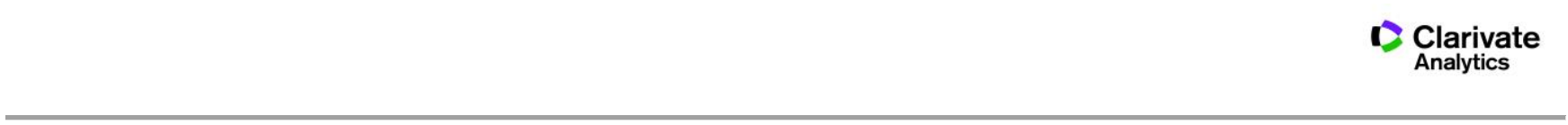

\title{
LONG-TERM IMPACT OF NATURAL DISASTERS ON VIETNAMESE INCOME PER CAPITA:
} THE CASE OF TYPHOON DURIAN*

\author{
Khac Hieu Nguyen ${ }^{1}$, Thi Thu Tra Pham ${ }^{2}$ \\ ${ }^{l}$ Ho Chi Minh City University of Technology and Education, Vietnam \\ ${ }^{2}$ RMIT University Vietnam, Ho Chi Minh City, Vietnam \\ E-mails: ${ }^{1}$ hieunk@hcmute.edu.vn (Corresponding author); ${ }^{2}$ tra.pham@ rmit.edu.vn
}

Received 3 April 2020; accepted 30 June 2020; published 30 September 2020

\begin{abstract}
This study estimates the effect of natural disasters on Vietnamese income per capita in both short and long-term. The analysis also evaluates the effects by sources of income including income from salary; income from agriculture, fishery, forest; and income from industry, construction, trade, and services. Typhoon Durian happened in December 2006 in southern provinces of Vietnam is chosen for the comparative case study. The analysis applies the Synthetic control method (SCM) to construct a counterfactual with respect to two different control groups and conducts a permutation test for the estimated values. The results show that typhoon Durian decreased aggregate income per capita of the affected region and the effect was long lasting. The reduction of monthly income per capita was estimated to be 56,925 VND which accounts for $7.9 \%$ of the total income. The most affected source of income is from agriculture, forestry, and fishery.
\end{abstract}

Keywords: typhoon; income per capita; synthetic control method

Reference to this paper should be made as follows: Nguyen, K.H., Pham, T.T.T. 2020. Long-term impact of natural disasters on vietnamese income per capita: the case of typhoon Durian. Entrepreneurship and Sustainability Issues, 8(1), 590-603. http://doi.org/10.9770/jesi.2020.8.1(41)

JEL Classifications: E40, O11, Q54

\footnotetext{
* This work belongs to the project in 2020 funded by Ho Chi Minh City University of Technology and Education, Vietnam
} 


\section{ENTREPRENEURSHIP AND SUSTAINABILITY ISSUES}

ISSN 2345-0282 (online) http://jssidoi.org/jesi/

2020 Volume 8 Number 1 (September)

http://doi.org/10.9770/jesi.2020.8.1(41)

\section{Introduction}

Research on the impact of natural disasters often focus on the short-term, leaving much of the long-term impact unexplored (Noy and DuPont, 2018; Fakhry et al., 2018; Chehabeddine, Tvaronavičienè, 2020). One could speculate that in the short-term, farms destroyed by disasters have no harvesting, factories damaged by disasters have little output and hence a negative impact on output is inevitable. Speculation of long-term impacts of natural disasters is more complex. In the long-term, new crops will likely be planted on farms, damages at factories will likely be remedied and output will likely recover to equilibrium. Further, damage caused by natural disasters may enable better investment in new technology, and hence allow to achieve higher output in the longterm. Hence, long-term impacts of natural disasters can be positive, negative or neutral based on the post-disaster relief and post-disaster investments (Rempel, 2010).

Estimating a long-term impact of natural disasters is challenging, both empirically and theoretically. Theoretically, natural disasters do not have a clear-cut effect on output and economic growth over the long-term. Traditional neo-classical growth models predict that a negative capital shock following a natural disaster does not affect the rate of technological progress and therefore have little effect over the long-term growth. On the other hand, endogenous growth models based on creative destruction process argue that negative capital shocks may spur the process of reinvestment and upgrading of capital goods and thereby lead to higher growth (Caballero \& Hammour, 1994; Cavallo et al., 2013; Heger \& Neumayer, 2019). Endogenous growth models that assume increasing return to capital, however, predict a lower growth prospect. Empirically, to estimate the longterm effect, one must collect the data several years before disasters and several years after disasters. In some cases, data are not sufficiently available for making inference statistics. In addition, since there are many factors that can affect output in the long-term, it is difficult to separate the impact of disaster from the impact of other factors.

Most of existing empirical studies rely on household survey data to analyze the short-term impact of natural disasters. Whilst these studies differ with respect to the regions chosen as comparative case studies, the specific types of disasters and the methods used to estimate the impact of disasters, they largely find an income reducing effect of natural disasters for the short-term (Paxson, 1992; Thomas et al., 2010; Coffman \& Noy, 2012; Bui et al., 2014; Arouri et al., 2015; Gignoux and Menéndez, 2016; Karim, 2018; De Oliveira, 2019; Tselios \& Tompkins, 2019). The negative impact of natural disasters on income is estimated ranging from $1.9 \%$ for the case of storms happening in Vietnam in the study of Arouri et al. (2015) to 23\% for the case of floods happening in Vietnam in the study of Thomas et al. (2010).

From a policy perspective, long-term effects of natural disasters are as important as short-term effects (Lynham et al., 2017). Yet, empirical evidence on the long-term effects of natural disasters on economic growth is scarce with a few exceptions that show different results (Xiao, 2011; Coffman and Noy, 2012; and Alwis and Noy, 2019; Parida et al., 2020). Xiao (2011) uses time-series analysis to estimate the impact of the 1993 Midwest flood and confirmed that Midwest flood had no impact on personal income but had a positive impact on agriculture in the long-term. Coffman and Noy (2012) apply the SCM to estimate the impact of Hurricane Iniki on Hawaii Island. Using data retrieved from a database maintained by the University of Hawaii Economic Research Organization (UHERO) for the period 1975-1991, the revealed findings suggest that aggregate personal income was $12 \%$ lower than the case the hurricane would have not occurred. Similarly, Parida et al. (2020) find a negative impact of flood on real per capita GSDP in Indian states. Different from previous two studies, Alwis and Noy (2019) find an increase in household income in Sri Lanka eight years after the 2004 Indian Ocean tsunami. Using the Difference in Difference method with data collected from five household survey in 1995, 2002, 2006, 2009, and 2012, Alwis and Noy (2019) attribute the positive effect of the tsunami to the large amount of external relief Sri Lanka received in the aftermath of the disaster.

Empirical studies of the impact of natural disasters on income for Vietnam are exclusively focused on the shortterm impacts and only use household data retrieved from the Vietnam Household Living Standard Surveys (Thomas et al., 2010; Bui et al., 2014; Arouri et al., 2015). These studies reach the same conclusion that natural 


\section{ENTREPRENEURSHIP AND SUSTAINABILITY ISSUES}

ISSN 2345-0282 (online) http://jssidoi.org/jesi/ 2020 Volume 8 Number 1 (September) http://doi.org/10.9770/jesi.2020.8.1(41) disasters have negative impacts on household income. Thomas et al. (2010) conclude that $23 \%$ of welfare decreases because of riverine flood and $52 \%$ of welfare decreases because of a hurricane affecting the cities which have more than 500,000 people. Bui et al. (2014) find a decline of $6.9 \%$ and $7.1 \%$ for Vietnamese household income and expenditure respectively due to natural disasters. They also find that income inequality and poverty are also affected by natural disasters. And lastly, Arouri et al. (2015) find that household income per capita decreases by $1.9 \%$ in the commune affected by storms.

The present study is a first attempt to investigate the effects of natural disasters on income per capita both in short-term and long-term for the case of Vietnam. Typhoon Durian which occurred in 2006 in the southern provinces of Vietnam was chosen as the case study. Storms and typhoons are common in Vietnam as well as in other countries (CRED, 2018a). Hence, findings of this study provide relevant policy implications with respect to alleviation of the impact of natural disasters at both short- and long-term basis, for similar events like typhoon Durian. Different from previous studies which are focused on the impact of natural disasters on aggregate income or total income, this paper investigates effects of typhoon Durian by income source, including income from salary; income from agriculture, fishery, forest; and income from industry, construction, trade and services. This approach provides an insightful understanding of the types of households that are most prone to adverse effects of the typhoon. Policy implications drawn on findings of this study will therefore be more targeted and effective, whereby policymakers can prioritize disaster aids to households whose income is most affected by natural disasters, helping speed up the recovery process.

In this study, following Abadie and Gardeazabal (2003), Abadie et al. (2010), we use the SCM to construct a counterfactual and implement permutation test for the estimated values. The study provides several key contributions. First, it contributes to limited evidence of the long-term impact of natural disasters on income with an application of the SCM. It also extends the analysis of the impact of natural disasters on disaggregated sources of income rather than aggregate income per capita. The paper proceeds as follows. The next section presents an overview of Vietnam's economy and typhoon Durian. Section 3 discusses the methodology of synthetic control which is followed by an empirical specification and relevant tests. Section 4 describes the data and presents an empirical analysis. Section 5 discusses the findings and the final section concludes the paper.

\section{Vietnam and typhoon Durian}

Vietnam is located in tropical region with a long coastline of $3260 \mathrm{~km}$, Vietnam is often affected by tropical storms in the coastline area and floods after storms because of rainfall (Desinventar, 2018). According to the report of CRED (2018b), Vietnam is one of the top ten countries affected by natural disasters. In 2017, natural disasters in Vietnam caused 316 deaths and 3.1 billion US\$ damage accounted for $1.4 \%$ of Vietnam's GDP. Vietnam Income per capita in PPP dollars from 2012-2014 is \$3771 with an average income growth rate of 6.5\% (World Bank, 2018). Vietnam is still considered as lower middle-income country. In addition, according to GSO (2018), Vietnamese income from agriculture, forestry, and fishery accounts for $27.2 \%$ of total income for the period 2002-2014. This income is more easily affected by storms and floods than the income from industry because farm and forest are destroyed directly by storm and flood while factories can just close down during the time of disaster to mitigate the impacts.

On November 26, 2006, a tropical depression intensified into a storm and was named Durian by the Japan Meteorological Agency (JMA). Strengthening of the storm took place over the following days and become a typhoon on November 29, 2006. Typhoon Durian affected mostly Philippine and Vietnam with the maximum wind speed of $195 \mathrm{~km} / \mathrm{h}$. Durian struck southern Vietnam on December 5, 2006 as a tropical storm and after that it diminished to a tropical depression. Durian hit mostly southern provinces of Vietnam such as Ba Ria-Vung Tau, Ben Tre, Tra Vinh, Soc Trang, Bac Lieu, and Ca Mau. According to the Centre for Research on the Epidemiology of Disasters (CRED), typhoon Durian killed 95 people and caused property damage of 456 million USD in Vietnam. For more details, see the map of Vietnam and track of typhoon Durian in Figure 1. 


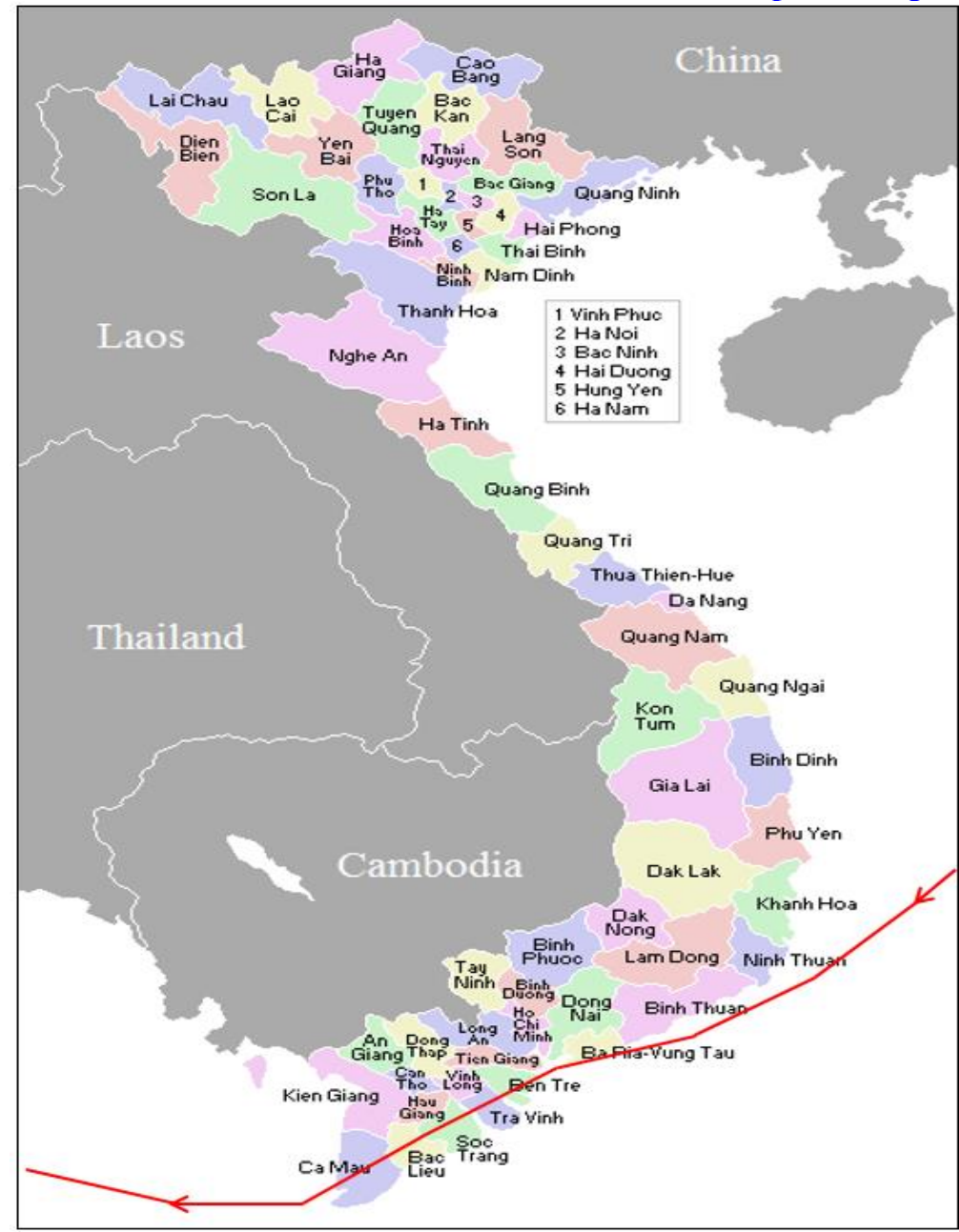

Figure 1. Map of Vietnam and track of typhoon Durian

Source: Authors' preparation using data from Japan Meteorological Agency

In this study, typhoon Durian was selected as a typical disaster for the case study on three accounts. Firstly, typhoon Durian was one of the top five natural disasters happened in Vietnam from 2002-2014 (Desinventar, 2018). Secondly, typhoon Durian mostly affected the southern provinces of Vietnam that are notably characterized with a low frequency of natural disasters compared to the central and northern provinces of Vietnam.

This allows a good choice of Ben Tre - a southern province as the treatment group as this province was affected by Durian but not affected by any other disasters afterward. Thirdly, 2006 is an appropriate timing to analyze possible impacts of the typhoon because the required economic data are essentially available both prior and post the typhoon. Specifically, data on disaster damage and characteristics of 63 provinces of Vietnam are available from 2002-2006 for choosing the control groups and data on income per capita are available from 2007-2014 for estimating the effects of typhoon Durian. 


\section{ENTREPRENEURSHIP AND SUSTAINABILITY ISSUES}

ISSN 2345-0282 (online) http://jssidoi.org/jesi/

2020 Volume 8 Number 1 (September)

\section{Methodology}

http://doi.org/10.9770/jesi.2020.8.1(41)

\subsection{Synthetic control method}

Synthetic control method (SCM) is considered a quasi-experiment in which the result is the difference between treatment group and control group. This method was first introduced by Abadie and Gardeazabal (2003) in a study of the effects of political conflicts on economic growth in the Basque Country. SCM was then applied in the study of Abadie et al. (2010) which evaluate the effect of the tobacco control program in California in 1988 on the consumption of tobacco. This method was also considered as a bridge between quantitative researches based on large sample and qualitative researches based on small sample (Abadie et al., 2015). Applications of SCM require a number of identification assumptions that are commonly used in quasi-experimental methods including independence between causing factor and control group, no spillovers cross units, no exogenous shocks, and the common support assumption. These assumptions have been discussed in detail in previous studies (Cavallo et al., 2013; Adhikari and Alm, 2016).

Independence between causing factor and control group requires that the control group be not affected by typhoon Durian. In order to satisfy this assumption, we remove all the province that were affected directly by typhoon Durian including Ba Ria-Vung Tau, Tra Vinh, Soc Trang, Bac Lieu, and Ca Mau (see the map of Vietnam in figure 1). In the aftermath of typhoon Durian, income spillover effects might occur to the provinces nearby Ben Tre because the reconstruction process places a surge in demand for labours and materials from neighbouring provinces. We can partially satisfy this assumption by excluding from the control group all provinces bordered with the provinces affected by typhoon Durian including Ba Ria-Vung Tau, Ben Tre, Tra Vinh, Soc Trang, Bac Lieu, and Ca Mau. This removes the following provinces from control group: Binh Thuan, Dong Nai, Tien Giang, Vinh Long, Hau Giang, and Kien Giang.

No exogenous shocks require that control groups be not affected by typhoon Durian and any other disasters during the time investigated. There are no such provinces because Vietnam is usually affected by floods and storms. Following Cavallo et al. (2013), we consider the magnitude of natural disasters based on which we select control groups as the provinces that were neither affected by typhoon Durian nor affected by "large disasters". We define large disasters based on the severity of damage, measured by the number of deaths and missing and the number of houses destroyed and damaged (see table 1). We choose two control groups to include provinces that did not suffer from top $1 \%$ and $10 \%$ of total disaster damage, respectively. Top $1 \%$ are provinces that have greater than 20 deaths and missing and greater than 3297 houses destroyed and damaged per million people in one year. Top 10\% are provinces that have greater than 6 deaths and missing and greater than 379 houses destroyed and damaged per million people in one year. Threshold numbers are calculated based on the percentile of provincial damage for the period 2002-2014.

We call these two control groups as Synth1\% (including 19 provinces: Bac Ninh, Binh Duong, Binh Phuoc, Ca Mau, Dak Nong, Dien Bien, Gia Lai, Hai Duong, Hoa Binh, Hung Yen, Khanh Hoa, Lam Dong, Nam Dinh, Nghe An, Ninh Thuan, Tay Ninh, Thanh Hoa, HCM City, Tuyen Quang) and Synth10\% (including 9 provinces: Bac Ninh, Binh Duong, Binh Phuoc, Gia Lai, Hai Duong, Hung Yen, Lam Dong, Tay Ninh, HCM City).

The common support assumption requires provinces included in the control group have similar characteristics to those of Ben Tre. Practically, this assumption is well addressed by the SCM as this method can produce counterfactual by a weighted combination of provinces in the control group. SCM uses algorithm to minimize the differences between treatment group and control group of specific of interest which are Income per capita and its predictors. 


\subsection{Modelling}

We call $\mathbf{J}$ the number of observations in control groups which consists of 19 and 9 provinces in two cases of analysis. Ben Tre is one observation in treatment group. Therefore, we have a total of $\mathrm{J}+1$ observations in the dataset. Following Abadie et al. (2010), let $Y_{i t}^{N}$ be the income per capita that would be observed for province i at time $\mathrm{t}$ that was not affected by disasters and $Y_{i t}^{I}$ is the income of province that was affected by disasters. For provinces, $i=\overline{1, J+1}$ and $t=\overline{1, T}$. Let $\mathrm{T}_{0}$ is the number of period before typhoon Durian happening $\left(1<\mathrm{T}_{0}<\mathrm{T}\right)$. So for the period before the disaster, we have $Y_{i t}^{N}=Y_{i t}^{I}$. For period after the disaster we use $\alpha_{i t}=Y_{i t}^{I}-Y_{i t}^{N}$ represent for the effect of the disaster to province $\mathrm{i}$ at time $\mathrm{t}$ for $t=\overline{T_{0}+1, T}$. Our interest is to compare the income of Ben Tre province that was affected by typhoon Durian with the income of other provinces that were not affected by the disaster. As such we will compute:

$$
\alpha_{1 t}=Y_{1 t}^{I}-Y_{1 t}^{N} \quad \text { for } \mathrm{t}>\mathrm{T}_{0}
$$

Of which $Y_{1 t}^{I}$ is the per capita income of Ben Tre province and $Y_{1 t}^{N}$ is the per capita income of the control group or per capita income of Ben Tre province if typhoon Durian did not happen. $Y_{1 t}^{I}$ is observed, but we do not know $Y_{1 t}^{N}$. SCM assumes that $Y_{1 t}^{N}$ is weighted average of $Y_{j t}$ for $j=\overline{2, J+1}$ or it can be calculated by this equation:

$$
Y_{1 t}^{N}==\sum_{j=2}^{J+1} w_{j} Y_{j, t} \text { with the constraints: } \mathrm{w}_{\mathrm{j}}>0 \text { and } \sum_{j=2}^{J+1} w_{j}=1
$$

In estimating $\mathrm{w}_{\mathrm{j}}$, we denote the matrices for the calculation as follows:

$$
W=\left[\begin{array}{c}
w_{2} \\
w_{3} \\
\cdot \\
\cdot \\
w_{J+1}
\end{array}\right] X_{1}=\left[\begin{array}{c}
X_{11} \\
X_{12} \\
\cdot \\
\cdot \\
X_{1 K}
\end{array}\right] X_{0}=\left[\begin{array}{ccccc}
X_{21} & X_{31} & \cdot & \cdot & X_{J+1,1} \\
X_{22} & X_{32} & \cdot & \cdot & X_{J+1,2} \\
\cdot & \cdot & \cdot & \cdot & \cdot \\
\cdot & \cdot & \cdot & \cdot & \cdot \\
X_{2 K} & X_{3 K} & \cdot & \cdot & X_{J+1, K}
\end{array}\right] V=\left[\begin{array}{ccccc}
V_{1} & 0 & . & \cdot & 0 \\
0 & V_{2} & \cdot & \cdot & 0 \\
\cdot & \cdot & \cdot & \cdot \\
\cdot & \cdot & \cdot & \cdot & \cdot \\
0 & 0 & \cdot & \cdot & V_{K}
\end{array}\right]
$$

$\mathrm{W}$ is the matrix $(\mathrm{J} \times 1)$ that contains the weight of the observations in the control group. $\mathrm{X}_{1}$ is a matrix $(\mathrm{K} \times 1)$ that contains explanatory variables for the changing of income per capita. $\mathrm{X}_{0}$ is the matrix $(\mathrm{K} \times \mathrm{J})$ containing the explanatory variables for the per capita income of the control group, which are similar to $\mathrm{X}_{1}$. V is the nonnegative diagonal matrix. From the notation we have $\left(\mathrm{X}_{1}-\mathrm{X}_{0} \mathrm{~W}\right)$ is the difference between the treatment group and the control group. SCM estimates $\mathrm{W}_{\mathrm{j}}$ by minimizing this difference between the treatment group and the control group or minimizing the distance:

$$
\left\|X_{1}-X_{0} W\right\|_{V}=\sqrt{\left(X_{1}-X_{0} W\right)^{\prime} V\left(X_{1}-X_{0} W\right)}
$$

According to Abadie and Gardeazabal (2003), the matrix V represents the importance of the explanatory variables and can be defined by researchers. In this study, we assume that every explaining variable is equally important and accordingly set $\mathrm{V}$ matrix to unity.

\subsection{Statistical significance}

From equation (1), we denote the estimated impact as $\hat{\alpha}_{1 t}=Y_{1 t}^{I}-\hat{Y}_{1 t}^{N}$ where $\hat{Y}_{1 t}^{N}$ is the estimated value of control group. But we are not sure about the significance of the estimated value because of possible errors in data 
collection and estimation. So, we have to test the significance of the value $\hat{\alpha}_{1 t}$. Following Abadie et al. (2010), the estimated value will be tested by permutation test which is also called Placebo test.

In the permutation test, we assume that every province in the control group was also hit by typhoon Durian while they were actually not hit and we apply SCM accordingly to estimate these counterfactual impacts. This yields a distribution of the estimated values of all provinces in the control group. We then compare the estimated value of the treatment group and the distribution of estimated values of control group. Statistical significance is measured by P_value, calculated as follows:

$$
P_{-} \text {value }_{t}=\operatorname{Pr}\left(\hat{\alpha}_{j, t}^{P L(j)} \leq \hat{\alpha}_{1, t}\right) \quad \text { where } j=\overline{2, J+1}
$$

$\mathrm{P}_{-}$value $_{t}$ is the probability that estimated value of the treatment group is greater than estimated values of the control group in the year $t$. This value will be calculated and presented details in table 3.

\section{Data}

Data for this study includes natural disasters and economic data. Natural disasters data of 63 provinces in Vietnam from 2002 to 2014 were retrieved and compiled from Desinventar (2018) which was supported by United Nations Office for disaster risk reduction. Total number of observations at provincial level is 819 . The Desinventar data show the post-natural disaster damages represented by number of deaths, missing and number of houses destroyed and damaged for 63 provinces of Vietnam, as described in detail in table 1.

Table 1. Total natural disaster damages in Vietnam during 2002-2014

\begin{tabular}{|c|c|c|c|c|c|c|c|}
\hline No. & Provinces & $\begin{array}{l}\text { Deaths and } \\
\text { missing/ } \\
\text { mill.person }\end{array}$ & $\begin{array}{c}\text { Houses } \\
\text { destroyed and } \\
\text { damaged/ } \\
\text { thous.person }\end{array}$ & No. & Provinces & $\begin{array}{l}\text { Deaths and } \\
\text { missing/ } \\
\text { mill.person }\end{array}$ & $\begin{array}{c}\text { Houses } \\
\text { destroyed and } \\
\text { damaged/ } \\
\text { thous.person }\end{array}$ \\
\hline 1 & An Giang & 37.7 & 103 & 33 & Kien Giang & 0.9 & 0.2 \\
\hline 2 & $\begin{array}{l}\text { B.Ria- } \\
\text { V.Tau }\end{array}$ & 65.2 & 8.5 & 34 & Kon Tum & 45.4 & 2.4 \\
\hline 3 & Bac Giang & 9.6 & 2.7 & 35 & Lai Chau & 4.4 & 0.0 \\
\hline 4 & Bac Kan & 84.3 & 29.3 & 36 & Lam Dong & 80.7 & 1.0 \\
\hline 5 & Bac Lieu & 10.4 & 1.8 & 37 & Lang Son & 32.9 & 7.4 \\
\hline 6 & Bac Ninh & 1.9 & 0.0 & 38 & Lao Cai & 144.8 & 2.8 \\
\hline 7 & Ben Tre & 13.5 & 103.2 & 39 & Long An & 176.1 & 5.5 \\
\hline 8 & Binh Dinh & 144.1 & 24.8 & 40 & Nam Dinh & 19.9 & 9.0 \\
\hline 9 & Binh Duong & 2.5 & 0.3 & 41 & Nghe An & 74.7 & 22.9 \\
\hline 10 & Binh Phuoc & 0.0 & 0.1 & 42 & Ninh Binh & 390.9 & 14.6 \\
\hline 11 & Binh Thuan & 17 & 4.8 & 43 & Ninh Thuan & 45.1 & 14.1 \\
\hline 12 & $\mathrm{Ca} \mathrm{Mau}$ & 4.1 & 1.9 & 44 & Phu Tho & 3.3 & 0.6 \\
\hline 13 & Can Tho & 19.2 & 80.0 & 45 & Phu Yen & 67.6 & 2.3 \\
\hline 14 & Cao Bang & 54.6 & 6.0 & 46 & Quang Binh & 12.2 & 9.3 \\
\hline 15 & Da Nang & 143.5 & 16.0 & 47 & Quang Nam & 31.7 & 2.8 \\
\hline 16 & Dak Lak & 44.5 & 2.1 & 48 & Quang Ngai & 29.5 & 9.9 \\
\hline 17 & Dak Nong & 11.9 & 2.6 & 49 & Quang Ninh & 194.9 & 2.4 \\
\hline 18 & Dien Bien & 29.9 & 2.9 & 50 & Quang Tri & 252.2 & 650.4 \\
\hline 19 & Dong Nai & 1.9 & 1.9 & 51 & Soc Trang & 301.3 & 75.9 \\
\hline 20 & Dong Thap & 72.5 & 39.9 & 52 & Son La & 426.7 & 20.6 \\
\hline 21 & Gia Lai & 11.5 & 0.3 & 53 & Tay Ninh & 66.7 & 11.5 \\
\hline
\end{tabular}




\section{ENTREPRENEURSHIP AND SUSTAINABILITY ISSUES}

ISSN 2345-0282 (online) http://jssidoi.org/jesi/ 2020 Volume 8 Number 1 (September)

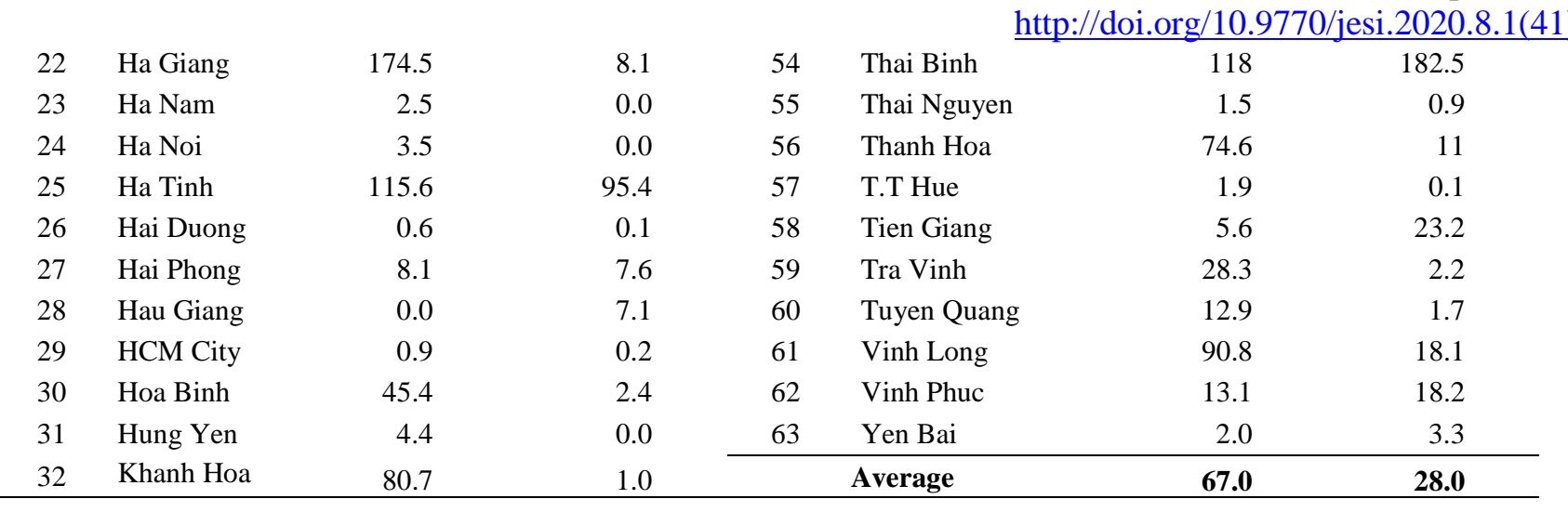

Source: compiled by authors from Desinventar.net

Economic data was collected from General Statistics Office of Vietnam (GSO, 2018) from 2002-2014. Data includes aggregate income per capita (A_Income) which represents our key dependent variable, and income disaggregated by sources such as income from salary (S_Income), income from agriculture, fishery and forestry (AFF_Income) and income from industry, construction, trade, and services (NAFF_Income).

Following Noy and $\mathrm{Vu}$ (2010) who studied the impact of natural disasters on economic growth in Vietnam, we used Infrastructure, Trade, Education, Healthcare, all measured at the provincial level, as control variables in the present study. Infrastructure, measured by the amount of goods transported, is a main factor explaining economic growth as suggested by Sahoo and Dash (2009); Chakamera and Alagidede (2018) in their studies on the role of infrastructure on economic growth in South Asian and Sub Saharan Africa countries.

Domestic Trade, measured by retail sales per capita as proxy for Trade, is considered an important indicator underlying commercial activities and hence economic output and income (Noy and Vu, 2010).

Healthcare measured by the number of doctors per capita represents the intensity of healthcare whereas Education measured by the number of students per capita represents the level of education, as commonly done in previous studies (Ramirez and Nazmi, 2003; Noy and Vu, 2010; Kuo and Shiu, 2016).

In line with a cross-country study by Cavallo et al. (2013) estimating the impact of natural disaster on economic growth during 1970-2008, we also use Land, measured as land area per capita as a control variable. Income from agriculture, fishery and forestry is affected by production from agriculture, fishery, and forestry. According to Tran (2014), paddy is a common agricultural crop, wood and fish are the common output for forestry and fishery, respectively.

Hence, when estimating income from agriculture, fishery, and forestry we include annual yield of paddy (Paddy), annual production of wood (Wood), and annual production of fish (Fish) as control variables.

Data for all control variables is collected from GSO (2018). All economic variables were converted to fixed price in 2010 using respective consumer price indices. Table 2 presents the average value of economic data of the case study. 
ENTREPRENEURSHIP AND SUSTAINABILITY ISSUES

ISSN 2345-0282 (online) http://jssidoi.org/jesi/ 2020 Volume 8 Number 1 (September)

http://doi.org/10.9770/jesi.2020.8.1(41)

Table 2. Average value of all variables

\begin{tabular}{|c|c|c|c|c|c|c|c|}
\hline \multirow[t]{2}{*}{ Variables } & \multirow[t]{2}{*}{ Unit } & \multicolumn{3}{|c|}{ Before typhoon Durian from 2002-2006 } & \multicolumn{3}{|c|}{ After typhoon Durian from 2007-2014 } \\
\hline & & Ben Tre & Synth $1 \%$ & Synth $10 \%$ & Ben Tre & Synth $1 \%$ & Synth $10 \%$ \\
\hline A_Income & Thous.VND/month & 465.25 & 504.65 & 589.7 & 723.72 & 815.2 & 974.78 \\
\hline S_Income & Thous.VND/month & 132.71 & 147.67 & 195.6 & 216.95 & 320.48 & 387.7 \\
\hline AFF_Income & Thous.VND/month & 167.4 & 171.51 & 157.28 & 229.99 & 216.63 & 233.43 \\
\hline NAFF_Income & Thous.VND/month & 89.78 & 109.35 & 143.34 & 159.44 & 185.08 & 245.48 \\
\hline Trade & Mill.VND/person/year & 3.58 & 4.86 & 5.93 & 11.39 & 14.58 & 7.94 \\
\hline Infrastructure & Ton*km/person/year & 0.18 & 0.31 & 0.32 & 0.27 & 0.54 & 0.54 \\
\hline Healthcare & Doctors/thous.person & 1.71 & 1.76 & 1.63 & 2.31 & 2.13 & 1.99 \\
\hline Education & Students/thous.person & 192.51 & 228.31 & 229.38 & 165.17 & 174.92 & 194.38 \\
\hline Land & $\mathrm{Km}^{2} /$ thous.person & 1.84 & 4.65 & 4.58 & 1.87 & 5.18 & 4.12 \\
\hline Paddy & Ton/person/year & 0.28 & 0.67 & 0.46 & 0.28 & 0.48 & 0.5 \\
\hline Wood & $\mathrm{M}^{3} /$ person/year & 0.01 & 0.05 & 0.03 & 0.00 & 0.06 & 0.05 \\
\hline Fish & Ton/thous.person/year & 105.77 & 59.59 & 20.7 & 217.94 & 56.54 & 34.94 \\
\hline
\end{tabular}

Source: calculated by Authors from GSO.

\section{Results and discussions}

We estimated the impacts of typhoon Durian on aggregate income per capita (A_Income) and three disaggregated sources of income including income from salary (S_Income), income from agriculture, fishery and forest (AFF-Income) and income from industry, construction, trade and services (NAFF_Income), respectively. To estimate the impact of typhoon Durian, SCM was used to compute a counterfactual. This means that control groups should have the same characteristics as treatment group. In this study, control groups were provinces that have the same income, land area, infrastructure, trade, healthcare, and education as Ben Tre province. For a robust result, we analyze two control groups including provinces that did not suffer from top $1 \%$ and $10 \%$ of total disaster damage. We call these two cases as Synth1\% and Synth10\%. Figure 2 shows the trend income of Ben Tre and income of control groups and table 3 shows placebo test for the estimated results.

The results show that typhoon Durian has negative impact on aggregate income per capita both in the short-term and long-term. The monthly average reduction is 56,925 VND for the period 2007-2014. The reduction of income accounts for $7.9 \%$ of total household income. This finding supports the hypothesis "no recovery" as also confirmed by Hsiang and Jina (2014). This hypothesis argues that disasters destroy productive capital or durable consumption goods and households do not have enough resources to recover from this negative impact. The recovery is even harder for poor/developing countries that are endowed with limited resources and underdeveloped infrastructure systems (Noy \& DuPont, 2018). Vietnam is not an exception with income per capita of 2006 at current prices is 636,000 VND/month, equivalent to 477 US dollars/year (GSO, 2018). In addition, Ben Tre is situated in middle of the Mekong river delta where there are nine rivers passing through the region. The use of ferries, rather than bridges, for crossing the river is still common, making it harder for households in Ben Tre to access resources in other provinces.

With respect to disaggregated sources of income, the estimated impact of the typhoon differs as per income source. Income from salary and income from agriculture, fishery and forest are found negatively affected by typhoon Durian from 2007-2014 while there is a positive impact of the typhoon on income from industry, construction, trade, and services from 2009-2012. Durian reduced income from salary by 55,395 VND and reduced income from agriculture, fishery, and forestry by 106,047 VND monthly for the period 2007-2014 
compared with the two control groups. This occurred because many factories could not operate in the aftermath of the disaster, workers did not receive salary and farmers did not have income from farming due to the crop damage. On the contrary, income from industry, construction, trade, and services of Ben Tre province was higher than that of provinces in the control groups in the period of 3 to 5 years after the typhoon. Theory of creative destruction process offers a possible explanation whereby the reconstruction activities that take place in the aftermath of natural disasters can raise the demand for construction and related services. The impact could be attributed to an increased demand for post-disaster reconstruction as proposed by Cavallo et al. (2013); Caballero and Hammour (1994). Since 2012, the results show a negative impact again, probably because the demand of reconstruction disappeared.
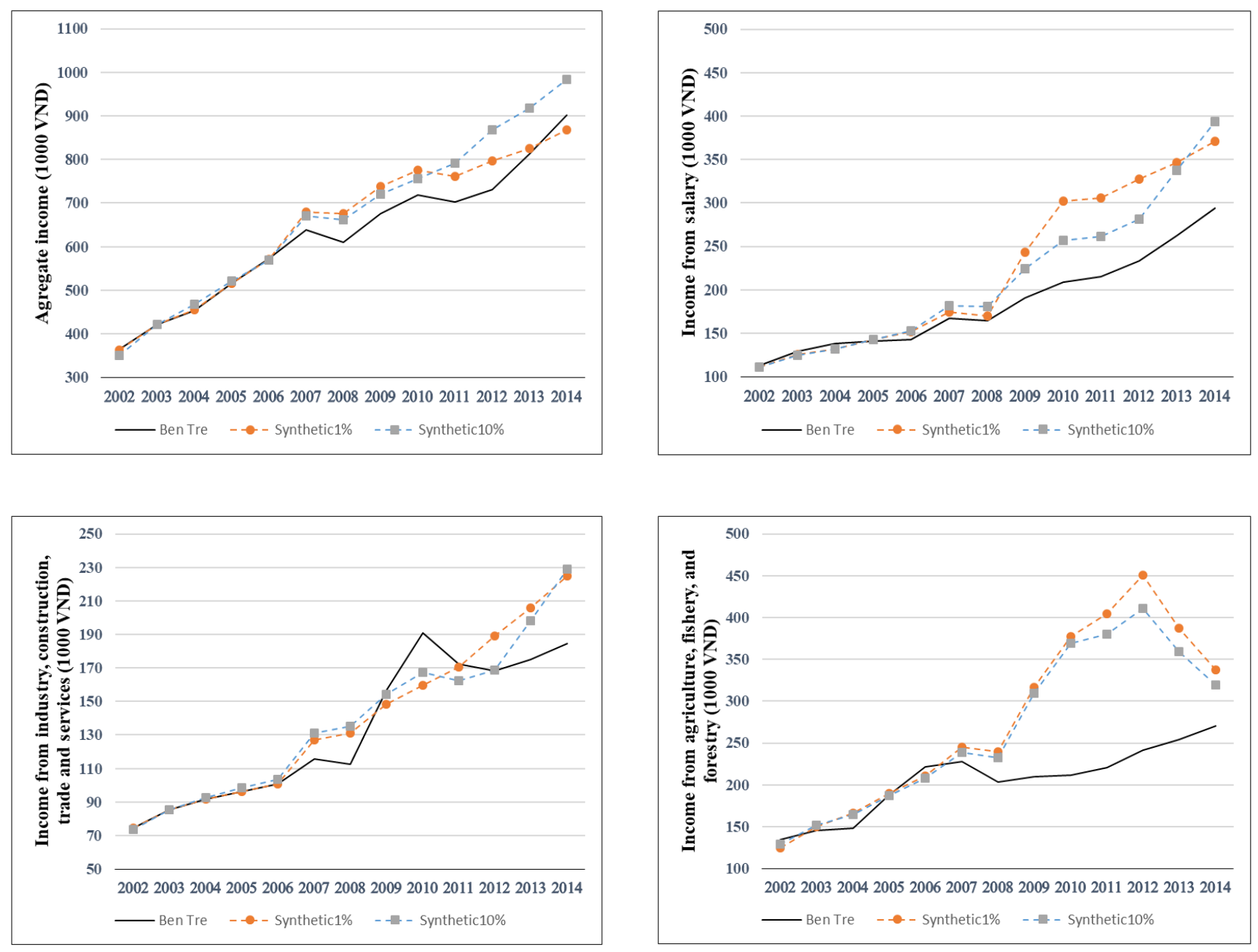

Figure 2. Income per capita, aggregated and disaggregated: Ben Tre vs. control provinces

The significance of the results is especially important. In this case, one could question whether income of Ben Tre province was indeed reduced by typhoon Durian or that was only random results. Following Abadie et al. (2010), we use the permutation test to check the results. SCM is applied for the provinces included in the control groups as if they were affected by typhoon Durian. This so-called Placebo test provides a distribution of the estimated results, based on which we compare the results between the aggregate income of Ben Tre and 
ENTREPRENEURSHIP AND SUSTAINABILITY ISSUES

ISSN 2345-0282 (online) http://jssidoi.org/jesi/ 2020 Volume 8 Number 1 (September) http://doi.org/10.9770/jesi.2020.8.1(41) provinces in the control groups. The test results as presented in table 3 indicate that typhoon Durian caused a statistically significant negative impact on all the sources of income after typhoon Durian except income from industry, construction, trade, and services for the period 3-5 years after the event.

Table 3. Statistical significance of estimated results by Placebo test

\begin{tabular}{|l|l|l|l|l|l|l|l|l|}
\hline \multirow{2}{*}{ Year } & \multicolumn{2}{|c|}{ Aggregate income } & \multicolumn{2}{|c|}{ Income from salary } & \multicolumn{2}{c|}{$\begin{array}{c}\text { Income from industry, } \\
\text { construction, trade, and } \\
\text { services }\end{array}$} & \multicolumn{2}{|c|}{$\begin{array}{c}\text { Income from } \\
\text { agriculture, forestry, and } \\
\text { fishery }\end{array}$} \\
\cline { 2 - 9 } & Synth1\% & Synth10\% & Synth1\% & Synth10\% & Synth1\% & Synth10\% & Synth1\% & Synth10\% \\
\hline $\mathbf{2 0 0 7}$ & $-3.52 * * *$ & $-2.46 * *$ & $-2.23 * *$ & $-2.00 * *$ & $-3.17 * * *$ & $-3.20 * * * *$ & $-2.71 * * *$ & -0.47 \\
\hline $\mathbf{2 0 0 8}$ & $-5.27 * * *$ & $-3.41 * * *$ & $-2.28 * *$ & $-2.27 * *$ & $-3.10 * *$ & $-2.83 * *$ & $-5.45 * * *$ & $-1.98 * *$ \\
\hline $\mathbf{2 0 0 9}$ & $-4.48 * * *$ & $-2.64 * *$ & $-5.54 * * *$ & $-2.31 * *$ & 0.16 & -0.99 & $-11.84 * * *$ & $-3.02 * * *$ \\
\hline $\mathbf{2 0 1 0}$ & $-3.63 * * *$ & $-1.96 * *$ & $-6.52 * * *$ & $-2.19 * *$ & 2.43 & 0.95 & $-12.87 * * *$ & $-3.00 * * *$ \\
\hline $\mathbf{2 0 1 1}$ & $-4.18 * * *$ & $-3.55 * * *$ & $-6.58 * * *$ & $-2.69 * *$ & -0.4 & -0.21 & $-10.56 * * *$ & $-3.50 * * *$ \\
\hline $\mathbf{2 0 1 2}$ & $-4.35 * * *$ & $-4.72 * * *$ & $-6.45 * * *$ & $-2.29 * *$ & $-2.04 * *$ & -0.66 & $-9.28 * * *$ & $-3.86 * * *$ \\
\hline $\mathbf{2 0 1 3}$ & $-2.39 * *$ & $-4.48 * * *$ & $-4.96 * * *$ & $-2.48 * *$ & $-1.94 * *$ & -1.23 & $-7.59 * * *$ & $-3.37 * * *$ \\
\hline $\mathbf{2 0 1 4}$ & -0.81 & $-3.14 * * *$ & $-3.92 * * *$ & $-2.54 * *$ & $-1.81 * *$ & $-1.48 *$ & $-4.65 * * *$ & $-3.04 *$ \\
\hline
\end{tabular}

Note: Table 3 presents t-statistics of the difference in aggregate income per capita between the treatment group and control group. *, **, $* * *$ represent the significance at $10 \%, 5 \%$, and $1 \%$ respectively. Source: estimated by authors.

\section{Conclusions}

We applied SCM to investigate the effect of typhoon Durian that occurred in Ben Tre province (Vietnam) in 2006 on aggregate income per capita and income disaggregated by sources. The analysis uses data on natural disasters and economic data at the provincial level during the period 2002-2014. Our results document an income reducing effect of the typhoon Durian on aggregate income per capita of Ben Tre and confirm that the effect lasted eight years after the event. This finding provides support of the hypothesis of no recovering after natural disasters, as also confirmed by previous studies for other countries (Coffman and Noy, 2012; Barone and Mocetti, 2014; Hsiang and Jina, 2014).

By source of income, our results also reveal a negative and long-lasting impact of typhoon Durian on income from salary and income from agriculture, fishery, and forest. The most affected income sources include income from agriculture, fishery, and forestry. A possible policy implication drawn on this finding is that policymakers should prioritize post-disaster relief programs to households that primarily receive income from agriculture, fishery, and forestry. Better targeted post-disaster relief program will help speed up the recovery process, especially for disasters similar to Durian.

The study merits some attentions for future research. One of SCM assumptions requires no spillover effect from the affected area to the control group. We partially controlled for this by technically removing from the control group provinces that are bordered with Ben Tre. In order to fully satisfy this assumption, more empirical studies are needed to estimate the spillover effects of natural disasters. In addition, income from agriculture, fishery, and forest collected from the General Statistics Office of Vietnam are aggregate data for the entire sector. Therefore, the present analysis could not estimate the impact of natural disasters on income of each sub-sector of agriculture, forestry or fishery. If one could separate income from agriculture, forestry, and fishery, the results would be more policy relevant. 


\section{ENTREPRENEURSHIP AND SUSTAINABILITY ISSUES}

ISSN 2345-0282 (online) http://jssidoi.org/jesi/ 2020 Volume 8 Number 1 (September)

http://doi.org/10.9770/jesi.2020.8.1(41)

\section{References}

Abadie, A., \& Gardeazabal, J. (2003). The economic costs of conflict: A case study of the Basque country. American Economic Review, 93(1), 113-132. https://doi.org/10.1257/000282803321455188

Abadie, A., Diamond, A., \& Hainmueller, J. (2010). Synthetic Control Methods for Comparative Case Studies: Estimating the Effect of California's Tobacco Control Program. Journal of the American Statistical Association, 105(490), 493-505. https://doi.org/10.1198/jasa.2009.ap08746

Abadie, A., Diamond, A., \& Hainmueller, J. (2015). Comparative Politics and the Synthetic Control Method. American Journal of Political Science, 59(2), 495-510. https://doi.org/10.1111/ajps.12116

Adhikari, B., \& Alm, J. (2016). Evaluating the economic effects of flat tax reforms using synthetic control methods. Southern Economic Journal, 83(2), 437-463. https://doi.org/10.1002/soej.12152

Alwis, D. De, \& Noy, I. (2019). Sri Lankan households a decade after the Indian Ocean tsunami. Review of Development Economics. https://doi.org/10.1111/rode.12586

Arouri, M., Nguyen, C., \& Youssef, A. B. (2015). Natural Disasters, Household Welfare, and Resilience: Evidence from Rural Vietnam. World Development, 70. https://doi.org/10.1016/j.worlddev.2014.12.017

Barone, G., \& Mocetti, S. (2014). Natural disasters, growth and institutions: A tale of two earthquakes. Journal of Urban Economics, 84, 52-66. https://doi.org/10.1016/j.jue.2014.09.002

Bui, A. T., Dungey, M., Nguyen, C. V., \& Pham, T. P. (2014). The impact of natural disasters on household income, expenditure, poverty and inequality: Evidence from Vietnam. Applied Economics, 46(15), 1751-1766. https://doi.org/10.1080/00036846.2014.884706

Caballero, R. J., \& Hammour, M. L. (1994). The Cleansing Effect of Recessions. The American Economic Review, 84(5), 1350-1368. https://doi.org/10.1126/science.151.3712.867-a

Cavallo, E., Galiani, S., Noy, I., \& Pantano, J. (2013). Catastrophic Natural Disasters and Economic Growth. The Review of Economics and Statistics, 95(December), 1549-1561. https://doi.org/10.2139/ssrn.1817292

Chakamera, C., \& Alagidede, P. (2018). The nexus between infrastructure (quantity and quality) and economic growth in Sub Saharan Africa. International Review of Applied Economics, 32(5), 641-672. https://doi.org/10.1080/02692171.2017.1355356

Chehabeddine, M., Tvaronavičienè, M. (2020). Securing regional development. Insights into Regional Development, 2(1), 430-442. http://doi.org/10.9770/IRD.2020.2.1(3)

Coffman, M., \& Noy, I. (2012). Hurricane Iniki: Measuring the long-term economic impact of a natural disaster using synthetic control. Environment and Development Economics, 17(2), 187-205. https://doi.org/10.1017/S1355770X11000350

CRED, C. for R. on the E. of D. (2018a). Economic Losses, Poverty and Disasters 1998-2017. In UNISDR. https://doi.org/10.1111/j.1469-7610.2010.02280.x

CRED, C. for R. on the E. of D. (2018b). Natural disasters in 2017: Lower mortality, higher cost. UNISDR.

Desinventar. (2018). Disaster Information System. UNISDR. http://118.70.74.167:8081/DesInventar/main.jsp

Fakhry, B., Aktan, B., Masood, O., Tvaronavičienè, M., Celik, S. (2018). The Impact Of A Recent Natural Disaster On The Japanese Financial Markets: Empirical Evidenece. Journal of Competitiveness, 10(2), 56-71. https://doi.org/10.7441/joc.2018.02.04

Gignoux, J., \& Menéndez, M. (2016). Benefit in the wake of disaster: Long-run effects of earthquakes on welfare in rural Indonesia. Journal of Development Economics, 118, 26-44. https://doi.org/10.1016/i.jdeveco.2015.08.004

GSO. (2018). General Statistics Office of Vietnam. Statistical Yearbook of Vietnam. https://www.gso.gov.vn/Default_en.aspx?tabid=491

Heger, M. P., \& Neumayer, E. (2019). The impact of the Indian Ocean tsunami on Aceh's long-term economic growth. Journal of Development Economics, 141, 102365. https://doi.org/10.1016/j.jdeveco.2019.06.008

Hsiang, S. M., \& Jina, A. S. (2014). Microorganisms in activated sludge and biofilm processes. Proceedings of a conference on microorganisms in activated sludge and biofilm processes, Paris, September 1993. In NBER WORKING PAPER SERIES.

Karim, A. (2018). The Household Response to Persistent Natural Disasters: Evidence from Bangladesh. World Development, 103. https://doi.org/10.1016/j.worlddev.2017.10.026 


\section{ENTREPRENEURSHIP AND SUSTAINABILITY ISSUES}

ISSN 2345-0282 (online) http://jssidoi.org/jesi/ 2020 Volume 8 Number 1 (September)

http://doi.org/10.9770/jesi.2020.8.1(41)

Kitaura, K., \& Yakita, A. (2010). School Education, Learning-by-Doing, and Fertility in Economic Development. Review of Development Economics, 14(4), 736-749. https://doi.org/10.1111/j.1467-9361.2010.00585.x

Kuo, M. Y., \& Shiu, J. L. (2016). A dynamic quantitative evaluation of higher education return: evidence from Taiwan education expansion. Journal of the Asia Pacific Economy, 21(2), 276-300. https://doi.org/10.1080/13547860.2015.1137472

Lynham, J., Noy, I., \& Page, J. (2017). The 1960 Tsunami in Hawaii: Long-Term Consequences of a Coastal Disaster. World Development, 94, 106-118. https://doi.org/10.1016/j.worlddev.2016.12.043

Mertens, K., Jacobs, L., Maes, J., Kabaseke, C., Maertens, M., Poesen, J., Kervyn, M., \& Vranken, L. (2016). The direct impact of landslides on household income in tropical regions: A case study from the Rwenzori Mountains in Uganda. Science of the Total Environment, 550, 1032-1043. https://doi.org/10.1016/j.scitotenv.2016.01.171

Morris, S. S., Neidecker-Gonzales, O., Carletto, C., Munguía, M., Medina, J. M., \& Wodon, Q. (2002). Hurricane Mitch and the livelihoods of the rural poor in Honduras. World Development, 30(1), 49-60. https://doi.org/10.1016/S0305-750X(01)00091-2

Mottaleb, K. A., Mohanty, S., Hoang, H. T. K., \& Rejesus, R. M. (2013). The effects of natural disasters on farm household income and expenditures: A study on rice farmers in Bangladesh. Agricultural Systems, 121, 43-52. https://doi.org/10.1016/j.agsy.2013.06.003

Noy, I., \& DuPont, W. (2018). The Long-Term Consequences of Disasters: What Do We Know, and What We Still Don't. International Review of Environmental and Resource Economics, 12(4), 325-354. https://doi.org/10.1561/101.00000104

Noy, I., \& Vu, T. B. (2010). The economics of natural disasters in a developing country: The case of Vietnam. Journal of Asian Economics, 21(4), 345-354. https://doi.org/10.1016/j.asieco.2010.03.002

Parida, Y., Saini, S., \& Chowdhury, J. R. (2020). Economic growth in the aftermath of floods in Indian states. Environment, Development and Sustainability. https://doi.org/10.1007/s10668-020-00595-3

Paxson, C. H. (1992). Using weather variability to estimate the response of savings to transitory income in Thailand. American Economic Review, 82(1), 15-33. https://doi.org/10.2307/2117600

Ramirez, M. D., \& Nazmi, N. (2003). Public investment and economic growth in Latin America: An empirical test. Review of Development Economics, 7(1), 115-126. https://doi.org/10.1111/1467-9361.00179

Rempel, H. (2010). The challenge of spending tsunami assistance well. Journal of the Asia Pacific Economy, 15(2), 106-127. https://doi.org/10.1080/13547861003700463

Sahoo, P., \& Dash, R. K. (2009). Infrastructure development and economic growth in India. Journal of the Asia Pacific Economy, 14(4), 351-365. https://doi.org/10.1080/13547860903169340

Thomas, T., Christianensen, L., Do, Q. T., \& Trung, L. D. (2010). Natural Disasters and Household Welfare Evidence from Vietnam. In Policy Research Working Paper (Vol. 5491). https://doi.org/10.1016/j.worlddev.2014.12.017

Tran, \& Thang Cong. (2014). Overview of Agricultural Polices in Vietnam (Issue 899).

Tselios, V., \& Tompkins, E. L. (2019). What causes nations to recover from disasters? An inquiry into the role of wealth, income inequality, and social welfare provisioning. International Journal of Disaster Risk Reduction, 33, 162-180. https://doi.org/10.1016/j.ijdrr.2018.10.003

World Bank. (2018). World Development Indicators - Google Public Data Explorer. GNI per Capita in PPP Dollars. https://www.google.com.vn/publicdata/explore?ds=d5bncppjof8f9_\&met_y=ny_gnp_pcap_pp_cd\&hl=en\&dl=en\#!ctype=1\&stra il=false\&bcs=d\&nselm=h\&met_y=ny_gnp_pcap_pp_cd\&scale_y=lin\&ind_y=false\&rdim=country\&idim=country:VNM\&ifdi $\underline{m}=$ country\&hl=en_US\&dl=en\&ind=false

Xiao, Y. (2011). Local economic impacts of natural disasters. Journal of Regional Science, 51(4), 804-820. https://doi.org/10.1111/j.1467-9787.2011.00717.x 


\section{ENTREPRENEURSHIP AND SUSTAINABILITY ISSUES}

ISSN 2345-0282 (online) http://jssidoi.org/jesi/

2020 Volume 8 Number 1 (September)

http://doi.org/10.9770/jesi.2020.8.1(41)

\section{Acknowledgement}

This work belongs to the project in 2020 funded by Ho Chi Minh City University of Technology and Education, Vietnam

Dr Khac Hieu NGUYEN is a lecturer in Economics at Ho Chi Minh City University of Technology and Education. He obtained a PhD degree in Economics in 2018 at University of Economics Ho Chi Minh City. His areas of research include natural disasters; economic development; innovation and firm performance.

ORCID ID: https://orcid.org/0000-0002-5138-2032

Dr Thi Thu Tra PHAM is a senior lecturer in the School of Business \& Management, RMIT Vietnam. She obtained her PhD in Economics from University of Groningen (the Netherlands) in 2006. Her current research interests include applied economics, economics of innovation, and international economics. Prior to joining RMIT, she served as a Senior Economist to a USAID-funded project advising the Government of Vietnam on international economic policy issues.

ORCID ID: $\underline{\text { https://orcid.org/0000-0001-7052-3323 }}$

Make your research more visible, join the Twitter account of ENTREPRENEURSHIP AND SUSTAINABILITY ISSUES:

@ Entrepr69728810

Copyright (C 2020 by author(s) and VsI Entrepreneurship and Sustainability Center

This work is licensed under the Creative Commons Attribution International License (CC BY).

http://creativecommons.org/licenses/by/4.0/

\section{c) (i) Open Access}

